\title{
Multimedia Application Development using Autoplay Media Studio 7.0 for Youth Electrical Engineering Training in Bontopannu
}

\author{
Hasdar Hanafi ${ }^{1}$, Ahmad Yani Ranius ${ }^{2}$, Yayan Sudrajat ${ }^{3}$, Iman Nurjaman ${ }^{4}$, Ismail Marzuki ${ }^{5}$, \\ Syakirah $^{6}$, Ahmed Heikal Andromeda ${ }^{7}$ \\ \{hasdar.ilmiah@gmail.com¹, ay_ranius@binadarma.ac.id ${ }^{2}$, yayan.sudrajat@unindra.ac.id ${ }^{3}$, \\ nurjamaniman@gmail.com ${ }^{4}$, \\ ismailmarzuki_tp17s3@mahasiswa.unj.ac.id ${ }^{5}$, syakirahalwy@gmail.com $^{6}$, perseonn@ gmail.com $\left.{ }^{7}\right\}$ \\ STKIP Yapis Dompu ${ }^{1}$, Universitas Bina Darma ${ }^{2}$, Universitas Indrapasta PGRI Jakarta ${ }^{3}$, Universitas \\ Muhammadiyah Tangerang ${ }^{45}$, Universitas Negeri Jakarta ${ }^{56}$, Pradita Institute ${ }^{7}$

\begin{abstract}
This research is a development research (R \& D) aimed at developing a conceptual models, physical models of electronic skills teaching materials and the effectiveness of teaching materials using the program Autoplay 7.0. The method in this study is adaptation of the ADDIE model. The results showed that learning using media Autoplay 7.0 on the techniques of maintenance and repair of telecommunications equipment was declared valid, practical and effective use of instructional media in Bontopannu Village, Pangkep Regency. Validation of material experts with a total average score of 3.5 is in the valid category and from the validation of media experts with a total average score of 3.23 is in the valid category. Based on the results of the analysis of the response of trainers and trainees in the category very well, it is stated to be practical and effective for use in learning.
\end{abstract}

Keywords: Media, autoplay 7.0, development

\section{Introduction}

Creativity in learning by using a variety of media (audio, visual, animated motion, etc.) will produce maximum cognitive processes. With simple language, it is said that there is a mistake in view by giving a lot of things (text, images, animations and so on) so that students in this case get more information. Learning with many media is known as multimedia-based learning. Multimedia as a means of education has at least two senses, namely a combination of various kinds of media (printed material / text, audio, video, slides, radio broadcasts, television broadcasts), each of which stands alone but programmed. An important component of multimedia is visualization which is one way that can be done to realize something abstract. Two-dimensional or three-dimensional images are visualization into a very useful approach to learning that helps to build creativity.

In general, media can be understood as everything, objects, or even a school environment that allows students to acquire knowledge, attitudes, and skills. In this case, lecturers, books and school environments can be understood as media. More specifically the notion of media in the teaching and learning process tends to be interpreted as graphical, photographic, or electronic devices to 
capture, process, reconstruct visual or verbal information, thus the media becomes two important parts of material (objects) and equipment (equipment) [1].

The teaching and learning processbased on PERMENDIKNAS Number 24 of 2007 concerning facilities and infrastructure explaining that the National Education Standards are related to minimal criteria about study rooms, sports venues, places of worship, libraries, laboratories, workshops, playgrounds, vacation spots and creative and other learning resources needed to support the learning process, including the use of information and communication technology. Furthermore, it was strengthened by Presidential Decree No. 50/2000 concerning Procurement of the Indonesian Telematics Coordination Team which refers to the use of ICT in various sectors and aspects of life, including in the field of Education [1].

In this case, coastal communities or youth groups cannot be separated from education. So, it can be concluded that the teaching and learning process does not look at the profession, learning is a necessity of life "self-generating", which strives for itself, because from birth humans have the drive to live their lives. Humans learn continuously to be able to achieve independence and adapt to various environmental changes [1].

Based on these descriptions, this article develops audio-video learning multimedia that is expected to provide learning experiences for coastal communities by displaying components through audio-visual media. Development of learning media must be directed to the effectiveness of learning in coastal communities. Thus, educators must be able to choose and use the right media in the material for developing audio-video-based electronic skills learning media in order to achieve optimal learning goals.

\section{Literature review}

\subsection{Multimedia pembelajaran}

According to Rosch multimedia is seen as a combination of computer and video [2], McCormick also states that multimedia is a combination of three elements, namely sound, images, and text [3]. Whereas mention multimedia as a base that can create dynamic and interactive presentations that combine text, graphics, animation, audio, and video. In the context of learning communication [4], multimedia can be seen as a computer use to create and combine text, graphics, audio, moving images (video and animation) by combining links and toots that allow users to navigate, interact, create, and communicate [5-7].

Multimedia can be used as an object of learning that can be reused repeatedly to support learning [8]. And although it is designed and made in small pieces but is able to maximize the objectives and a number of learning situations by utilizing existing resources [1]. This is in line with the opinion of Roy which states that the use of multimedia that is managed well can be a turning point in the process improvement learning [9].

The establishment of Multimedia Based Learning (PBM) is equipped with a virtual laboratory for the field of digital electronics. If seen from the learning activities can be done by anyone by providing facilities, a toolbar menu form among others: (1) Input, which consists of input switches, push button input, clock generator, logic 0, logic 1, (2) Simulation, which consists of 
animation star, stop animation, timing diagram simulation, (3) Tools, which consist of digital circuit simulation, fini type state machine simulation. (4) Learning machine, which consists of local demos deeds, material learning, website deeds. Activities that can be carried out by students while doing practical work in the field of electronics [1].

In this case, multimedia itself has an important role in terms of teaching and learning, because its use makes it easy for instructors to deliver teaching material to students both online and offline.

\subsection{Learning media}

Media (plural) is derived from the Latin word which is the form (singular) medium meaning "in between" (between). Media is in the middle between the sender of the message (sender) and the recipient (receiver, audience or communicant). Sadiman et al., defined that the media restrictions, namely: everything that can be used to deliver the message (message) from the sender to the recipient so that it can stimulate the mind, feelings, concerns and interests of students in a way that learning occurs [1].

Essentially, a learning process is a communication process, delivering a message of introduction to the receiver. Messages with content /teaching poured into symbols of communication, both verbal (word and writing) and nonverbal is called encoding. The interpretation of the symbols of the communication by the students is called decoding. This interpretation sometimes does not get success or failure. The failure to understand what is heard, read, seen or observed, caused by disorders that become an obstacle in the communication process known as barriers or noise. The more abstract understanding of verbal is increasingly accepted. Thus, what are the functions of the media?

The diagram cone of learning from Edgar Dale clearly gives the emphasis to the importance of media in education [1]. Generally, the media can function as follows:

1. to clarify the message that is not to verbalise.

2. to overcome the limitations of space, time, energy and resources senses.

3. to provide potential passion to learn, the more direct interaction between students with learning resources.

4. to allow children to learn independently according to their talents and abilities of visual, auditory and kinesthetic.

5. to provide the same stimuli, similar experience and to rise to the same perception.

\section{Method}

This research is a development research aimed to determine the development process, conceptual models, physical models of electronic skills teaching materials and the effectiveness of teaching materials using the program autoplay 7.0 which is focused on developing multimedia learning in the youth group of Bontopannu Village, Pangkep Regency. The development model used in this study is the development model $A D D I E$ which is carried out in several stages, namely (1) Analysis, (2) Design, (3) Development, (4) Implementation, (5) Evaluation [10]. The research data set can be accessed in osf.io Open Science Framework. 


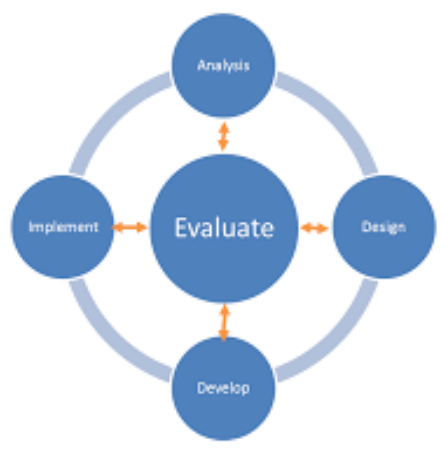

Fig. 1. ADDIE Models

\section{Result and discussion}

Multimedia learning developed, will be validated by two experts with a revision so that it is feasible to use. Trials were conducted three times, namely individual trials, small group trials and expanded trials. The results of the analysis that will be obtained by educators from learning media are in very good categories

\subsection{Instrument Validation}

Data retrieval is done using an instrument in the form of a questionnaire that has been validated by material experts and media experts in media development. The type of instrument that is validated is; questionnaire responses to trainees, trainer response questionnaires, table activity questionnaires, coach activity questionnaires, pre-post test questions.

The results of the average value of the total validation of the table response questionnaire are 3.00. Questionnaire response tables according to the validation category table and categorized as valid. So that the questionnaire can be used in research.

\subsection{One To One (Test A One)}

Trial Tests of readability were carried out on 3 (three) coastal teenagers in Bontopannu village and the results of the average value of 3.35 were included in the excellent category.

\subsection{Trial For Small Groups}

After the next legibility test was carried out a small group trial. This trial was conducted on 6 (six) people and the results obtained an average value of 3.46 included in the excellent category. So that it can proceed to the next stage, namely an expanded trial.4.4 Trial Expanded. Wider trial was conducted in three (3) meetings. The trainer presents basic electronic teaching materials using 
learning media for maintenance techniques and telecommunications equipment repairs. Two video tutorials for each sub-section of material, both software and hardware.

The results of the table response analysis show that the learning media of telecommunication equipment maintenance and repair techniques with an average total value of 3.38 in the excellent category. So, it was concluded that the learning media of electronic skills from the development results were responded positively by teenagers in Bontopannu Village, Pangkep Regency.

\subsection{Evaluation}

Learning media using autoplay 7.0 software on teaching materials for maintenance and repair of telecommunications equipment with evaluation of the results of development and implementation. From the evaluation results it was concluded that the learning media using autoplay 7.0 in the youth group of Bontopannu Village, Pangkep Regency were effectively and efficiently used in the learning process. This learning media also needs to be continuously developed following the development of science and technology in order to get better results. The following is a graph of the pre-post test results.

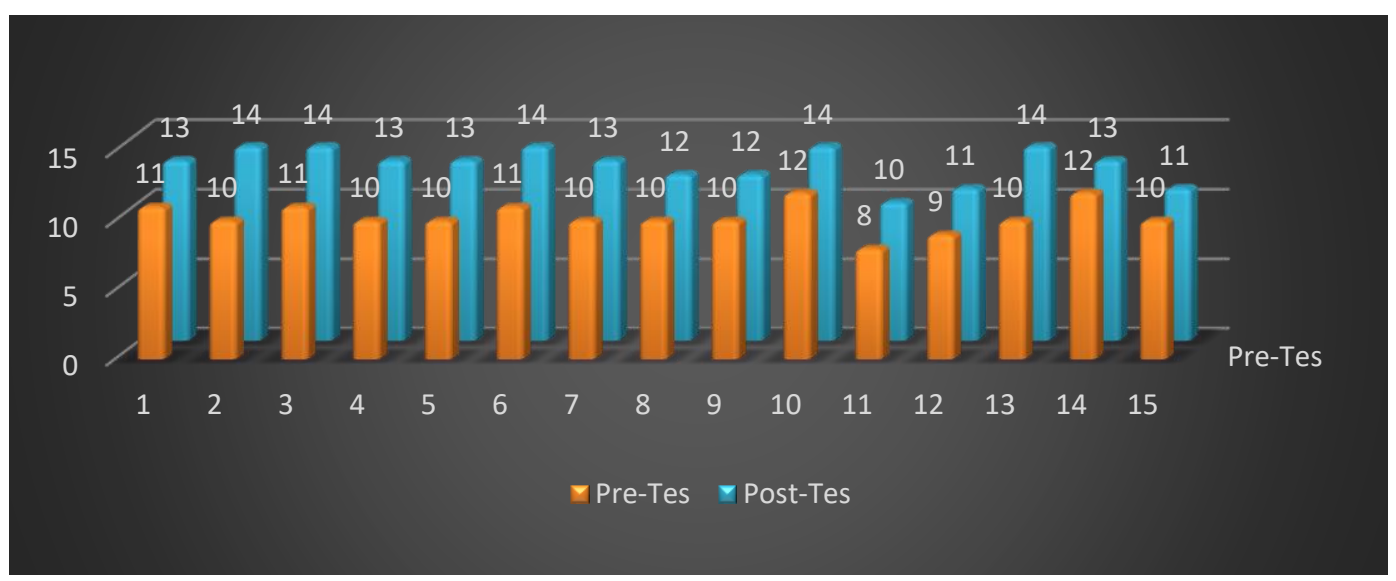

Fig. 2. Graph of 15 Results for Pre-Post Test Training Participants

\section{Conclusion}

The conceptual results and physical products resulting from this learning are Tutorial CDs, Handbooks for the use of media and Textbooks. Where it makes it easy for lay people to use the media. 


\section{Bibliography}

[1] V. S. Gerlach and D. P. Ely, Tecnología didáctica: Paidós, 1979.

[2] M. Maeda, et al., "Spiral stent," ed: Google Patents, 1996.

[3] P. McCormick, Patty McCormick's Pieces of an American Quilt: Quilts, Patterns, Photos \& Behind the Scenes Stories from the Movie: C \& T Pub., 1996.

[4] C. G. Begley, et al., "The relationship between habitual patient-reported symptoms and clinical signs among patients with dry eye of varying severity," Investigative ophthalmology \& visual science, vol. 44, pp. 4753-4761, 2003.

[5] W. N. H. W. Jusoh and K. Jusoff, "Using multimedia in teaching Islamic studies," Journal of Media and Communication Studies, vol. 1, pp. 086-094, 2009.

[6] R. A. Reiser, "A history of instructional design and technology: Part II: A history of instructional design," Educational technology research and development, vol. 49, pp. 57-67, 2001.

[7] D. V. Tesone and P. Ricci, "Fourth generation online learning: So far, so fast," in Southern Management Association 2003 Meeting, 2003, p. 402.

[8] D. A. Wiley, The instructional use of learning objects vol. 1: Agency for instructional technology Bloomington, IN, 2002.

[9] M. Roy, "Learning objects," EdUCAUSE Review, vol. 39, pp. 80-84, 2004.

[10] A. P. Benny, "Model desain sistem pembelajaran," Jakarta: Dian Rakyat, 2009. 